\title{
PKM Peningkatan Kualitias Ajar Guru dan Workshop Pembuatan Media Ajar Berbasis Animasi
}

\author{
Nurliana Nasution ${ }^{1}$, Feldiansyah Bakri Nasution ${ }^{2}$, Mhd Arief Hasan ${ }^{3}$ \\ 1,2,3Teknik Informatika Universitas Lancang Kuning, Pekanbaru, Indonesia \\ Email : nurliananst@unilak.ac.id ${ }^{1}$, feldiansyah@unilak.ac.id², m.arif@unilak.ac.id³
}

\begin{abstract}
Abstrak: Sekolah Dasar IT Luhuring Budi adalah sebuah sekolah yang mengedepankan pengembangan berbagai aspek potensi anak didik dan kecerdasannya serta pembentukan kepribadian muslim yang paripurna sedini mungkin. Sekolah ini menerapkan konsep pendidikan yang bertumpu pada Alqur'an dan Al Hadist.Sekolah Generus Luhuring Budi berdiri diatas tanah seluas 1945 m2 di Jalan Sri Kurnia RT/RW 05/05 Kelurahan Agrowisata Kecamatan Rumbai, Pekanbaru yang sekarang ini sedang ditata secara ekologis untuk menjadi sekolah yang asri, bersih, indah, tertib,aman, dan nyaman sehingga tercipta lingkungan dan suasana belajar yang kondusif dan nyaman. Perkembangan teknologi informasi memungkinkan guru dapat membuat media pembelajaran sendiri karena saat ini banyak komputer berbasis grafis yang memudahkan pembuatan animasi. Teknologi ini memungkinkan pembuatan animasi dengan cara yang sangat mudah dan murah dibandingkan dengan tahun-tahun sebelumnya. Dulu, diperlukan penggunaanan animasi tradisional cenderung bersitr'at mahal dan menghabiskan banyak waktu untuk proses pembuatannya" Untuk sekarang, banyak tersedia perangkat lunak yang memungkinkan para guru menciptakan sendiri media belajar dalam bentuk animasi.Tidak butuh keterampilan khusus untuk dapat membuat media belajar yang murah, menyenangkan, dan menarik minat belajar siswa. Pemanfaatan media grafis ini dimanfaatkan oleh para guru untuk mengembangkan kesempatan mereka mengajar menggunakan animasi computer yang menggambaran konten dinamis. Berikut adalah uraian terntang dua permasalahan prioritas yang dihadapi mitra:Peningkatan Kualitas Pengajaran, dan Produk Pengajaran. Solusi dari kegiatan ini Memberikan Pelatihan materi peningkatan kualitas pengajaran. Pembuatan Materi Ajar menggunakan website Animaker. Kegiatan ini dilaksanakan pada hari Sabtu 17 Juni 2021, bertempat di salah satu ruangan kegiatan belajar mengajar Sekolah Dasar Islam Terpadu (SD IT) Luhuring Budi. Kegiatan pelatihan ini berupa Pelatihan materi peningkatan kualitas pengajaran,Workshop Pembuatan Animasi Pembelajaran Berbasis Multimedia,Monitoring Pasca Pelaksanaan Pelatihan dan Workshop
\end{abstract}

Kata Kunci: Aplikasi, Media, Pelatihan, Pembelajaran, SD

Abstract: IT Luhuring Budi Elementary School is a school that prioritizes the development of various aspects of the potential of students and their intelligence as well as the formation of a complete Muslim personality as early as possible. This school applies the concept of education which is based on the Qur'an and Al Hadith. Generus Luhuring Budi School stands on a land area of $1945 \mathrm{m2}$ on Jalan Sri Kurnia RT/RW 05/05 Agrowisata Village, Rumbai District, Pekanbaru which is currently being ecologically organized to become a a beautiful, clean, beautiful, orderly, safe, and comfortable school so as to create a conducive and comfortable learning environment and atmosphere. The development of information technology allows teachers to create their own learning media because there are currently many graphics-based computers that make it easier to create animations. This technology allows the creation of animation in a very easy and inexpensive way compared to previous years. In the past, it was necessary to use traditional animation, which tended to be expensive and spent a lot of time in the manufacturing process. " For now, there are many software available that allow teachers to create their own learning media in the form of animation. No special skills are needed to be able to create cheap learning media, fun, and attract students' interest in learning. The use of graphic media is used by teachers to develop their opportunities to teach using computer 
animation that depicts dynamic content. The following is a description of two priority problems faced by partners: Improving the Quality of Teaching, and Teaching Products. Solutions from this activity provides training on teaching quality improvement materials. Making teaching materials using the Animaker website. This activity will be held on Saturday 17 June 2021, taking place in one of the teaching and learning activities rooms at the Luhuring Budi Integrated Islamic Elementary School (SD IT). This training is in the form of training in teaching quality improvement materials, Workshops on Making Multimedia-Based Learning Animations, Monitoring Post-Training and Workshops.

Keywords: Apps, Media, Training, Learning, Elementary School

\section{Pendahuluan}

Sekolah Dasar Islam Terpadu Luhuring Budi adalah sebuah sekolah yang mengedepankan pengembangan berbagai aspek potensi anak didik dan kecerdasannya serta pembentukan kepribadian muslim yang paripurna sedini mungkin. Sekolah ini menerapkan konsep pendidikan yang bertumpu pada Alqur'an dan Al Hadist.

Sekolah Dasar Islam Terpadu Luhuring Budi berdiri diatas tanah seluas 1945 m2 di Jalan Sri Kurnia RT/RW 05/05 Kelurahan Agrowisata Kecamatan Rumbai, Pekanbaru yang sekarang ini sedang ditata secara ekologis untuk menjadi sekolah yang asri, bersih, indah, tertib,aman, dan nyaman sehingga tercipta lingkungan dan suasana belajar yang kondusif dan menyenangkan.

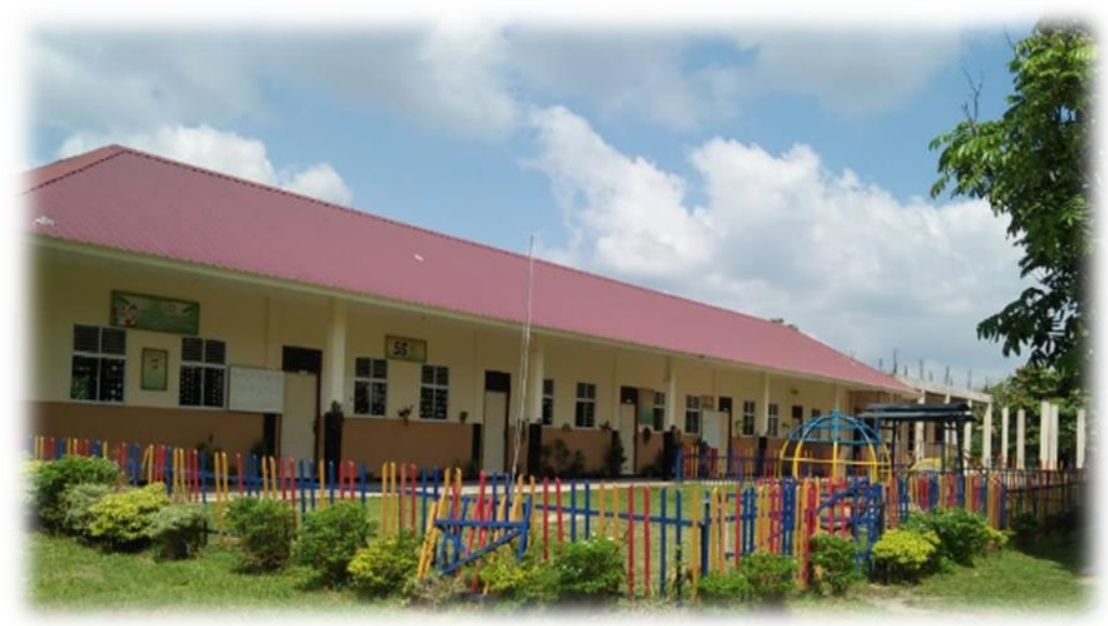

Gambar 1 : SD IT Luhuring Budi Kelurahan Agrowisata

Dalam bidang pengembangan Akademik, Sekolah Generus Luhuring Budi menggunakan Kurikulum Nasional dengan keunggulan lokal yang telah di kembangkan oleh Tim Pengembangan Kurikulum Sekolah Dasar Islam Terpadu Luhuring Budi dengan memadukan nilai -nilai ajaran Islam dan konsep - konsep islam tentang manusia (human), ilmu (knowledge), dan alam semesta (universe). Selain itu aspek pendidikan Lingkungan Hidup, pendidikan kepemimpinan (Leadership) dan pendidikan kewirausahaan (Enterpreneurship) adalah bagian yang tak terpisahkan dari seluruh program pendidikan dengan mengintegrasikannya kedalam semua mata pelajaran dan kegiatan ekstrakurikuler. Sekolah ini juga memiliki Kurikulum Pendidikan Islam dan pengamalannya serta Pendidikan Al Qur'an yang disusun khusus oleh Tim Pengembangan Kurikulum Generus Luhuring Budi.

Untuk melahirkan generasi muslim yang Alim, Faqih serta sadar dan peduli lingkungan, program sekolah hijau Generus Luhuring Budi secara bertahap disusun secara 
holistik dengan mengaitkan keseluruhan program yang ada di sekolah serta mempertimbangkan berbagai faktor yang dapat berpengaruh, baik faktor pendukung atau faktor penghambatnya. Potensi internal sekolah yang berupa lahan, sumber daya air, energi dan limbah serta potensi sekitar sekolah seperti tradisi masyarakat, kondisi bentang alam dan ekosistemnya akan menjadi objek dalam program pengembangan sekolah hijau Generus Luhuring Budi.

Untuk mencapai cita-cita luhur di atas. Perlu ditopang dengan sarana dan prasarana memadai. SD IT saat ini terus berupaya dalam pemenuhan sarana dan prasarana tersebut. Disamping itu guna mencapai hal tersebut juga diperlukan upaya peningkatan kualitas sumber daya pendidik. Dengan berkembangnya abad 21 ditandai dengan perkembangan teknologi informasi tentu banyak merubah aspek-aspek dalam pendidikan (Wijaya et al., 2016). Bahan Ajar yang diberikan oleh pendidi harus memberikan nilai desain yang lebih guna menciptakan tantangan di mana peserta didik mampu berkolaborasi dalam memberikan solusi pemecahan masalah dalam pelajaran. Disamping itu pembelajaran abad 21 ini menuntut guru untuk bisa lebih kreatif,inovatif, mampu berpikir kritis, mampu dan mudah dalam mendapatkan informasi, berjiwa komunikatif dan kolaboratif, serta mampu menghargai perbedaan pendapat (Hasibuan \& Prastowo, 2019)(Sofwan et al., 2016).

Perkembangan teknologi informasi juga memungkinkan guru dapat membuat media pembelajaran sendiri karena saat ini banyak komputer berbasis grafis yang memudahkan pembuatan animasi (Andriyani \& Christy, 2018; Arif \& Arpin, 2021; Hardiyanti et al., 2020; Jambak et al., 2019; Mardhika \& Normawati, 2018). Teknologi ini memungkinkan pembuatan animasi dengan cara yang sangat mudah dan murah dibandingkan dengan tahun-tahun sebelumnya. Dulu, diperlukan penggunaanan animasi tradisional cenderung bersitr'at mahal dan menghabiskan banyak waktu untuk proses pembuatannya" Untuk sekarang, banyak tersedia perangkat lunak yang memungkinkan para guru menciptakan sendiri media belajar dalam bentuk animasi.Tidak butuh keterampilan khusus untuk dapat membuat media belajar yang murah, menyenangkan, dan menarik minat belajar siswa.

Pemanfaatan media grafis ini dimanfaatkan oleh para guru untuk mengembangkan kesempatan mereka mengajar menggunakan animasi computer yang menggambaran konten dinamis, misalnya pemanfaatan PowerPoint untuk membuat animasi yang sederhana dan mudah. Jika digunakan dengan tepat, bahkan perangkat lunak sederhana ini dapat menghasilkan animasi pendidikan yang efektif. Media belajar berupa animasi dapat menampilkan perubahan yang terjadi, dan cocok digunakan untuk pengajaran anak Sekolah Dasar yang kecenderungannya adalah pembelajaran visual.

\section{Metode}

Berdasarkan hasil diskusi bersama yang dilakukan oleh Tim Pengusul, maka ditentukan dua persoalan prioritas di SD IT Luhuring Budi Kelurahan Agrowisata yang akan diberikan solusi melalui program pengabdian masyarakat, yakni:

Tabel 1 : Kaitan Masalah Prioritas. Solusi dan Iptek yang digunakan

\begin{tabular}{|c|c|c|c|}
\hline Masalah Prioritas & & & IPTEK \\
\hline $\begin{array}{l}\text { Peningkatan } \quad \text { Kualitas } \\
\text { Pengajaran }\end{array}$ & $\begin{array}{l}\text { Pelatihan } \\
\text { peningkatan } \\
\text { pengajaran }\end{array}$ & $\begin{array}{r}\text { materi } \\
\text { kualitas }\end{array}$ & $\begin{array}{l}\text { Penggunaan model pembelajaran, metode } \\
\text { pembelajaran, media pembelajaran, dan } \\
\text { sumber belajar yang disesuaikan dengan } \\
\text { karakteristik peserta didik dan mata pelajaran. }\end{array}$ \\
\hline
\end{tabular}




\begin{tabular}{|l|l|l|}
\hline Produk Bahan Ajar & Pembuatan Animasi & Pembuatan Materi Ajar menggunakan website \\
& Pembelajaran & Animaker. \\
& a. Cara Menggunakan Animaker \\
& b. & Konsep Gerak di Animaker \\
& c. & Memberikan Efek Suara di Animaker \\
& d. Teknik Penggunaan Kamera di \\
& Animaker \\
& e. & Mengatur Ukuran Objek di Animaker \\
& f. & Menggunakan Time Line \\
& g. & Membuat Gif di Animaker \\
& h. & Mengganti Background di Animake \\
\hline
\end{tabular}

Kegiatan pengabdian masyarakat ini, tim pengabdian memberikan solusi terhadap permasalahan yang dihadapi mitra adalah sebagai berikut:

Tabel 2 : Kaitan Solusi, Metode, Koordinator dan Pihak yang terlibat

\begin{tabular}{|c|c|c|c|}
\hline Solusi & Metode dan tahapan & Kordinator & Pihak yang terlibat \\
\hline \multirow[t]{2}{*}{$\begin{array}{l}\text { Pelatihan materi } \\
\text { peningkatan } \\
\text { kualitas } \\
\text { pengajaran }\end{array}$} & $\begin{array}{l}\text { Pembuatan Portal Web UMKM Perabot } \\
\text { Rotan Atang } \\
\text { Tahapan dan prosedur keria: } \\
\text { a. Focus Group Discussion } \\
\text { b. Perancangan Modul Pelatihan Materi } \\
\text { Peningkatan Kualitas Pengajaran } \\
\text { c. Pembuatan Modul Pelatihan Pelatihan } \\
\text { Materi Peningkatan Kualitas } \\
\text { Pengajaran } \\
\text { d. Mencetak Modul Pelatihan Materi } \\
\text { Peningkatan Kualitas Pengajaran } \\
\text { e. Mencetak Kuisioner Pelatihan }\end{array}$ & $\begin{array}{l}\text { Mhd. Arief } \\
\text { Hasan, M.Kom } \\
\text { Dr Feldiansyah , } \\
\text { ST, MBuss(IT), } \\
\text { PhD } \\
\text { Dr. Nurliana } \\
\text { Nasution. S.T, } \\
\text { M.Kom }\end{array}$ & $\begin{array}{l}\text { Pihak Guru SD IT } \\
\text { Luhuring Budi, } \\
\text { Tim dosen dan } \\
\text { mahasiswa }\end{array}$ \\
\hline & $\begin{array}{l}\text { Pelatihan materi peningkatan kualitas } \\
\text { pengajaran } \\
\text { Tahapan dan prosedur kerja: } \\
\text { a. Penyampaian Materi } \\
\text { b. Tanya Jawab } \\
\text { c. Evaluasi } \\
\text { d. Monitoring dan evaluasi }\end{array}$ & $\begin{array}{l}\text { Dr. Nurliana } \\
\text { Nasution. S.T, } \\
\text { M.Kom }\end{array}$ & $\begin{array}{l}\text { Pihak Guru SD IT } \\
\text { Luhuring Budi Tim } \\
\text { dosen dan mahasiswa }\end{array}$ \\
\hline $\begin{array}{l}\text { Pembekalan } \\
\text { Animasi } \\
\text { Pembelajaran }\end{array}$ & $\begin{array}{l}\text { Workshop Marketing online dengan } \\
\text { materi sebagai berikut. } \\
\text { Tahapan dan prosedur kerja: } \\
\text { a. Cara Menggunakan Animaker } \\
\text { b. Konsep Gerak di Animaker } \\
\text { c. Memberikan Efek Suara di Animaker } \\
\text { d. Teknik Penggunaan Kamera di } \\
\quad \text { Animaker } \\
\text { e. Mengatur Ukuran Objek di Animaker } \\
\text { f. Menggunakan Time Line } \\
\text { g. Membuat Gif di Animaker } \\
\text { Mengganti Background di Animaker } \\
\text { Tahapan Evaluasi } \\
\text { a. Evaluasi } \\
\text { b. Monitoring dan evaluasi }\end{array}$ & $\begin{array}{l}\text { Mhd. Arief } \\
\text { Hasan, M.Kom } \\
\text { Dr Feldiansyah, } \\
\text { ST, MBuss(IT), } \\
\text { PhD } \\
\text { Dr. Nurliana } \\
\text { Nasution. S.T, } \\
\text { M.Kom }\end{array}$ & $\begin{array}{l}\text { Pihak Guru SD IT } \\
\text { Luhuring Budi dan } \\
\text { mahasiswa }\end{array}$ \\
\hline
\end{tabular}




\section{Hasil dan Pembahasan}

\subsection{Pelaksanaan Kegiatan}

Kegiatan ini dilaksanakan pada hari Sabtu 17 Juni 2021, bertempat di salah satu ruangan kegiatan belajar mengajar Sekolah Dasar Islam Terpadu (SD IT) Luhuring Budi. Pengabdian bertemakan teknologi informasi ini tidak pertama kali ini dilakukan tim pengabdian. Tercatat beberapa kegiatan serupa telah dilaksanakan pemateri (Nasution, 2018; Nasution et al., 2018, 2020, 2021; Nasution \& Hasan, 2019).

Materi diawali oleh pembukaan langsung oleh Kepala Sekolah SD IT Luhuring Budi yakni Hj.Robayani Spd, M.Pd. Pada pidato pembukaan ibu Kepala Sekolah SD IT Luhuring Budi menyambut baik kegiatan ini. Butuhnya guru akan muatan berupa transfer pengetahuan dari Perguruan Tinggi membuat terbentuknya peningkatatan kualitas SDM dari para pendidik dilingkungan Sekolah Dasar. Hj.Robayani Spd, M.Pd yang sebelumya juga merupakan Kepala Sekolah SD N 03 Pekanbaru juga menyampaikan bahwasanya, Pengayaan yang diberikan diharapkan guru akan mempunyai nilai daya saing yang lebih baik ke depannya. Guru dituntut untuk bisa menguasai penggunaan produk teknologi informasi. Cakap menggunakan produk teknologi berupa aplikasi yang bisa diterapkan untuk mengembangkan pembelajaran, membuat produk ajar yang lebih inovatif. Sehingga peserta didik pun menjadi lebih tertarik dalam proses pengajaran karena variasi yang diterapkan dalam metode pengajaran. Hal ini juga seiring dengan tema metode pengajaran abad 21 dimana guru bisa menjadi mentor, fasilitator, kolaborator, mentor, pelatih, pengarah dan teman belajar. Dimana salah satu skill yang harus dikuasai Guru Abad 21 ini yakni mampu menjadi Digital Desainer sebagai inovasi dalam menciptakan media ajar. Setelah kepala sekolah memberikan pengarahan kemudian dilanjutkan dengan materi utama dari tim pengabdian. Kegiatan tersebut berupa :

\subsubsection{Pelatihan materi peningkatan kualitas pengajaran}

Kegiatan ini disampaikan setelah pembukaan kegiatan Program Pengabdian Kepada Masyarakat. Materi ini disampaikan dalam bentuk metode ceramah dan penyampaian slide presentase. Tema kegiatan pelatihan ini merujuk terhadap metode pengajaran yang dilaksanakan pada Abad 21 ini. Penyampai materi pelatihan ini sendiri adalah Dr. Nurliana Nasution, S.T, M.Kom yang juga sekaligus ketua dari Tim Pengabdian Masyarakat ini.

Dalam Sesi penyampaiannya Dr Nurliana Nasution, S.T, M.Kom menyampaikan beberapa hal sebagai berikut :

a. Perkembangan teknologi Informasi pada Abad 21 ini sudah banyak merubah gaya hidup manusia baik dalam bekerja, berkomunikasi dengan lingkungan, kegiatan sehari-hari hingga pengaruhnya dalam dunia pendidikan. Dimana dulu kondisi pendidikan dan pengajaran berpusat sepenuhnya ke guru. Pada abad ini berpusat pada siswa didik dimana mengembangkan siswa didik yang lebih produktif dan mempunyai skill yang mumpuni.

b. Perkembangan teknologi informasi juga melahirkan produk-produk 
teknologi baik hardware dan software yang dapat memudahkan penggunanya. Hal ini juga berimplikasi terhadap dunia pendidikan. Dimana siswa didik dengan mudah dan gampangnya mencari referensi sumber pengetahun. Dibalik itu juga tuntutan guru untuk lebih cakap dalam penggunaan produk teknologi iinformasi tersebut. Sehingga dengan hal tersebut bisa menggunakannya untuk menciptakan produk kreatif untuk menghasilkan iklim dunia pendidikan yang lebih kreatif dan tidak monoton.

c. Perkembangan teknologi Informasi pada Abad 21 ini juga merubah metode pengajaran. Dimana dulunya pembelajaran berbasis kurikulum namun pembelajaran saat ini berbasis kemampuan siswa. Kalau dulu diarahkan sepenuhnya oleh guru namun sekarang pengarahan yang dimunculkan dari pribadi siswa. Dalam materi pelajaran dahulu berbicara apa saja yang harus diketahui namun pada abad 21 belajar bagaimana cara mendapatkannya. Dulu lebih banyak menghapal namun tuntutan abad 21 lebih cendrung berpikir. Dulu berbasis pengajaran namun saat ini lebih ke berbasis ekperimental. Pembelajaran sekarang lebih berfokus ke aktifan siswa yang dahulunya siswa bersifat pasif menerima saja. Tuntutan membuat sebuah team work untuk saat ini daripada dahulu berbasis individual atau kompetisi.

d. Beberapa skil yang harus dimiliki oleh guru pada abad 21 ini. Diantaranya Kemampuan dalam menguasai teknologi informasi dan mengakses media. Kemampuan untuk berpikir kritis, kemampuan untuk memecahkan masalah, kemampuan komunikasi efektif, dan kemampuan untuk bekerjasama dan berkolaborasi.

e. Beberapa peranan guru yang yang akan muncul pada abad 21 diantaranya fasilitator, kolaborator, pengarah, teman belajar, mentor, pelatih. Guru dapat memberikan pilihan dan tanggung jawab kepada siswa untuk mengalami proses pengajaran.

Diakhir materi ini peserta dan tim pemateri melakukan diskusi dan tanya jawab seputaran materi mengenai Metode Pembelajaran Abad 21. Pada pelaksanaan ini guru sangat antusias untuk bertanya mengenai metode pengajaran abad 21 ini. Hal ini dikarenakan mereka mengajar masih menggunakan metode konvensional. Dimana mereka mengakui metode konvensional ini membuat siswa cepat menjadi jenuh dan bosan. Mereka membutuhkan sekali suport dan dukungan agar adopsi pembelajaran abad 21 ini bisa bertahap diterapkan di sekolah mereka. Hal ini sebagai upaya untuk meningkatkan daya saing siswa dan guru. Kemudian tentunya berdampak terhadap terperolehnya siswa yang aktif dan mempunyai skill yang mumpuni. 


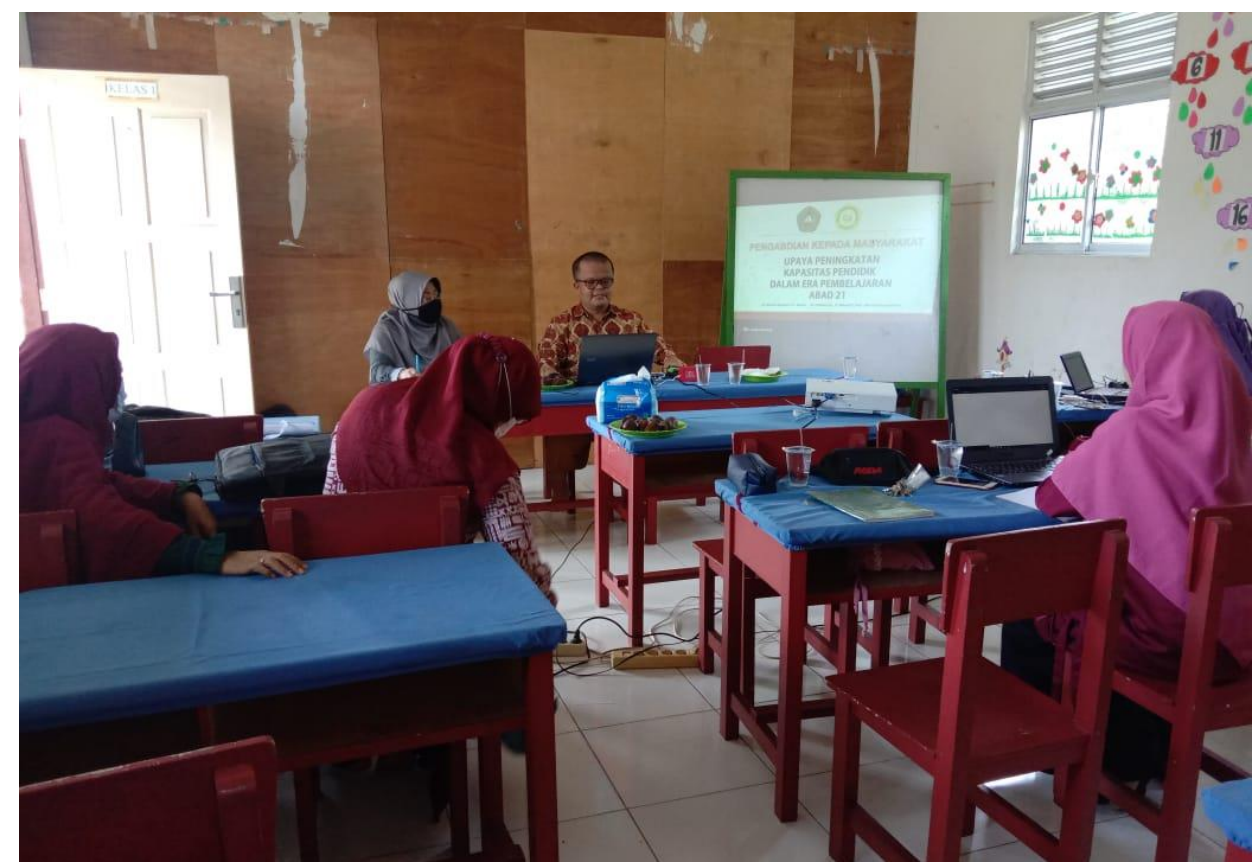

Gambar 2. Suasana Pelatihan Peningkatan Kualitas Pengajaran Guru

Pada Gambar 2 terlihat saat suasana pelatihan dimana pemateri memberikan materi mengenai peningkatan kualitas pengajaran. Tema yang diangkat berkaitan dengan peningkatan kualitas ajar dengan tema pengajaran pada abad 21.

\subsubsection{Workshop Pembuatan Animasi Pembelajaran Berbasis Multimedia}

Pada kegiatan berikutnya dilakukan pelatihan mengenai pembuatan animasi pembelajaran berbasis multimedia. Materi ini disampaikan langsung oleh Mhd Arief Hasan, M.Kom. Pelatihan ini menggunakan tool Animaker. Animaker Inc. adalah perangkat lunak animasi video. Perangkat lunak ini berbasis cloud, dan diluncurkan pada tahun 2014. Ini memungkinkan pengguna untuk membuat video animasi menggunakan karakter dan template yang sudah dibuat sebelumnya. Perangkat lunak ini menyediakan alat online untuk membuat dan mengedit animasi video. Perangkat lunak ini dikembangkan oleh Animaker Inc., Animaker dibangun di atas HTML5 dan membantu pengguna membuat video animasi yang dapat diekspor ke Facebook, YouTube, atau diunduh sebagai file MP4. Perangkat lunak ini juga tersedia sebagai ekstensi Chrome di Toko Web Chrome.

Materi pelatihan ini meliputi

1. Pengenalan Menu Interface dari aplikasi Animaker.

2. Teknik menambahkan scene pada layar.

3. Menggunakan Time Line untuk mengatur durasi, dan posisi objek.

4. Menggunakan Library untuk menentukan ekspresi dari objek.

5. Media kerja yang digunakan untuk menaruh objek yang kita inginkan.

6. Menambahkan objek baik tulisan, gambar, animasi maupun suara.

7. Menggunakan template hal ini ditujukan agar mempercepat proses kerja 
8. Menghasilkan video yang jadi dan siap diunduk peserta.

Pada kegiatan pelatihan ini peserta dihadapkan langsung dengan aplikasi yang mereka bisa akses dari PC mereka masing-masing. Kemudian tim pengabdian langsung mengenalkan dan mengajarkan teknik penggunaan aplikasi tersebut melalui tayangan infocus. Masing-masing peserta mengikuti pelatihan tersebut step by stepnya. Kemudian peserta diberikan studi kasus untuk membuat materi ajar menggunakan animaker. Hal ini dijadikan sebagai evaluasi dari kegiatan.

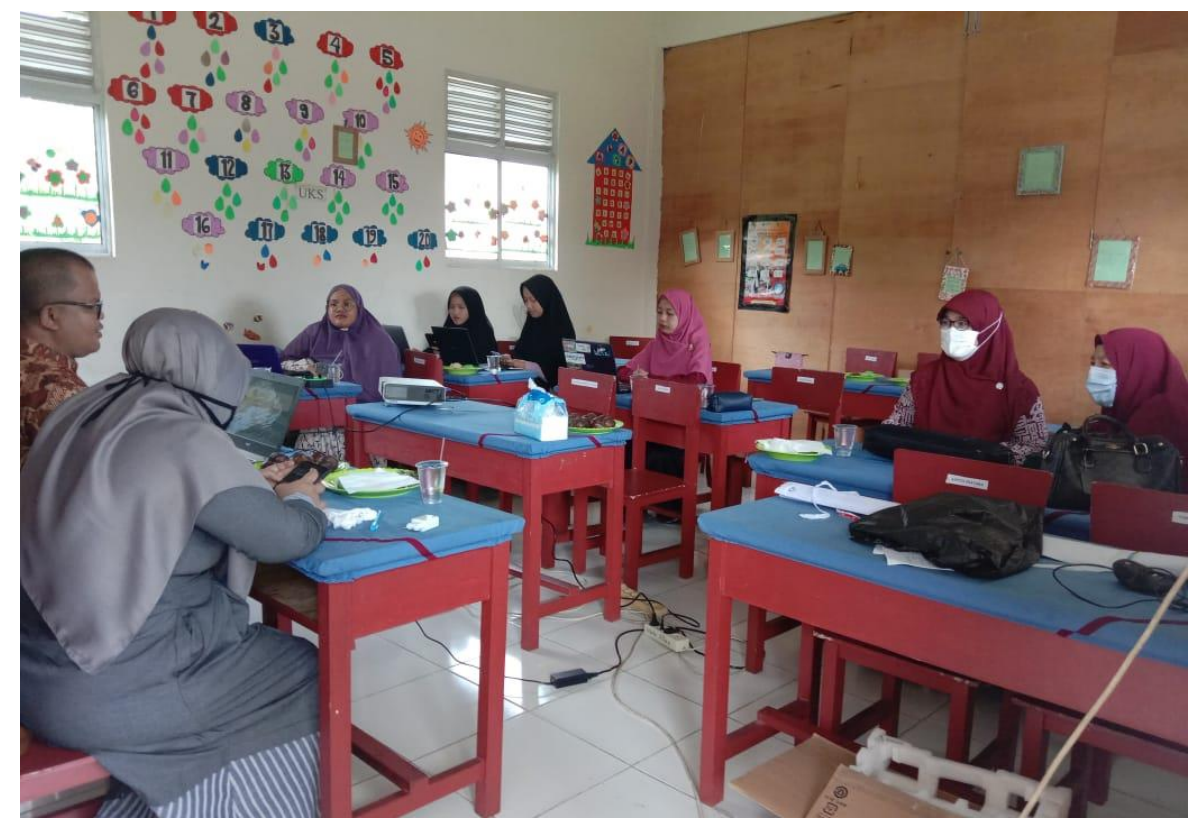

Gambar 3. Suasana saat pelatihan pembuatan animasi pembelajaran

Pada Gambar 3 tampak siswa sedang melakukan workshop pelatihan mengenai pembuatan Animasi pembelajaran menggunakan software animaker. Peserta dengan antusiasnya mengikuti kegiatan pelatihan.

\subsection{Monitoring Pasca Pelaksanaan Pelatihan dan Workshop}

Evaluasi dari kegiatan ini adalah merupakan tolak ukur dari capaian kegiatan. Dimana peserta diukur kemampuannya dalam pelaksanaan kegiatan. Beberapa tolak ukur capaian dilakukan untuk mengukur kemampuan peserta setelah dilakukan adanya kegiatan Pengabdian Kepada Masyarakat ini. Adapun bentuk pengukuran tersebut adalah sebagai berikut :

\subsubsection{Mengumpulkan hasil projek dari kegiatan workshop}

Setelah diadakan pelatihan mengenai pembuatan animasi multimedia pembelajaran. Pemateri melakukan evaluasi dengan mengumpulkan hasil karya seluruh peserta. Hasil tersebut digunakan sebagai acuan kemampuan peserta dalam memahami materi pelatihan. Dari hasil tugas yang dikumpulkan 99 persen peserta bisa menyelesaikan tugas yang diberikan pemateri. Adapun hasil yang dibuat peserta bisa dilihat pada gambar 3 . 


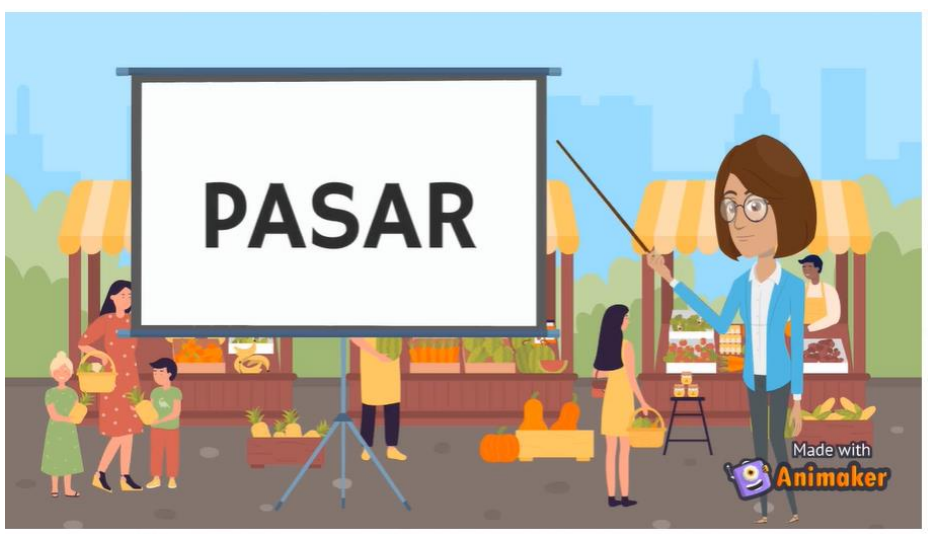

Gambar 4. Salah satu hasil karya peserta dalam pelatihan membuat animasi pembelajaran

Gambar 4 menjelaskan salah satu hasil karya peserta dalam pembuatan animasi pembelajaran. Adapun software yang digunakan adalah animaker. Peserta ini membuat materi pelajaran mengenai pasar. Hasil yang dibuat dikumpulkan dalam bentuk format video.

3.2.2 Mengukur kemampuan peserta sebelum dan sesudah pelatihan

Pada saat awal dan akhir kegiatan peserta diberikan kuisioner untuk mengukur kemampuan peserta sebelum dan sesudah pelatihan. Hal ini menjadi indikator bagi pemateri dalam menilai kemampuan peserta dalam menyerap materi pelatihan. Adapun hasil dari pengukuruan tersebut bisa dilihat dalam penyajian tabel dan grafik berikut.

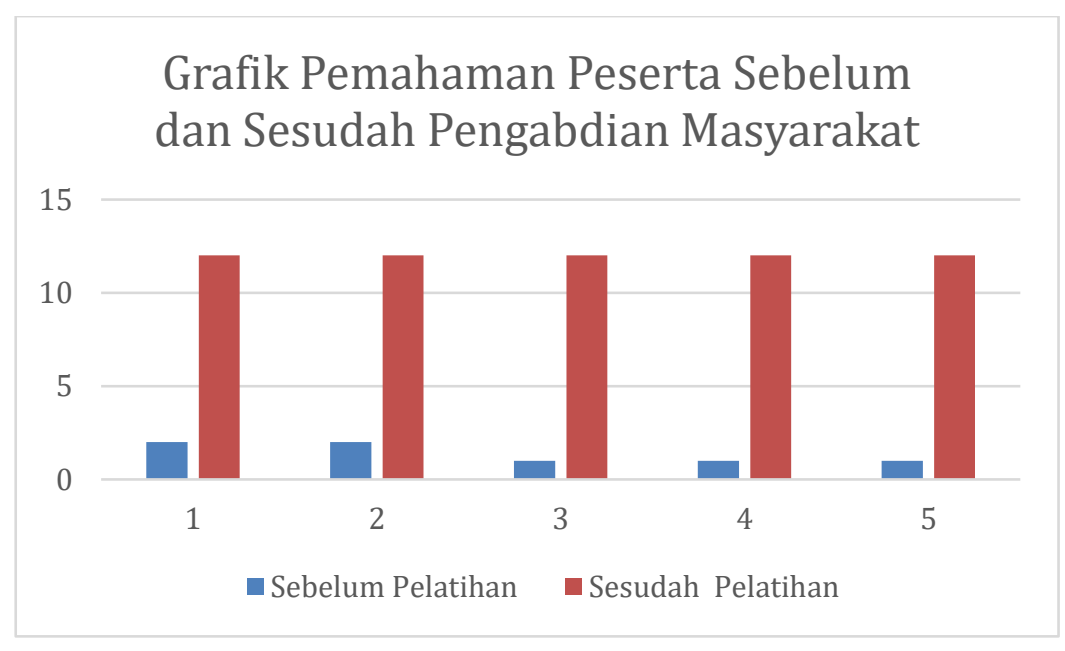

Gambar 5. Grafik Pemahaman Peserta sebelum dan sesudah pelatihan

Pada gambar 5 dijelaskan berupa adanya perubahan pemahaman peserta sebelum dan sesudah pelatihan. Pengukuran ini dilakukan dengan cara memberikan 
kuisioner kepada peserta di awal dan akhir pelatihan. Adapun indikator penilaiannya bisa dilihat pada Tabel 1.

Tabel 3. Indikator Penilaian Pengabdian Kepada Masyarakat

\begin{tabular}{clcc}
\hline ES. & \multicolumn{1}{c}{ Indikator } & $\begin{array}{c}\text { Sebelum } \\
\text { Pelatihan }\end{array}$ & $\begin{array}{c}\text { Sesudah } \\
\text { Pelatihan }\end{array}$ \\
\hline 1 & $\begin{array}{l}\text { Saya memahami mengenai perubahan metode } \\
\text { pengajaran pada Abad 21 }\end{array}$ & 2 & 12 \\
2 & $\begin{array}{l}\text { Saya mengetahui peran penting teknologi } \\
\text { informasi dalam pergeseran nilai pengajaran. }\end{array}$ & 1 & 12 \\
3 & $\begin{array}{l}\text { Saya memahami apa yang terjadi dalam } \\
\text { perubahan pengajara dalam abad 21 }\end{array}$ & 1 & 12 \\
$4 \quad \begin{array}{l}\text { Saya mengetahui aplikasi yang dapat membantu } \\
\text { saya dalam membuat animasi pembelajaran } \\
\text { Saya memahami animaker sebagai tool untuk } \\
\text { memudahkan dalam penyampaian animasi } \\
\text { pembelajaran }\end{array}$ & 1 & 12
\end{tabular}

Diakhir kegiatan ini diberikan kepada peserta dan pemateri berupa sertifikat pelatihan. Sertifikat ini tentunya membantu peserta dalam upaya pengakuan dalam proses peningkatan keterampilan guru. Dan juga sertifikat ini juga dapat digunakan sebagai bahan untuk kenaikan pangkat.

\section{Kesimpulan}

Setelah diadakan program pengabdian kepada masyarakat ini dengan tema Peningkatan Kualitias Ajar Guru dan Workshop Pembuatan Media Ajar Berbasis Animasi. Secara keseluruhan Pengabdian Kepada Masyarakat ini berjalan dengan sukses dan lancar. Hal ini didapat dari antusias peserta, output yang dihasilkan peserta, dan hasil kuisioner yang diberikan peserta. Didapat nilai seluruh peserta memahami topik yang diberikan pemateri.

Upaya pendampingan perlu dilakukan agar pelatihan ini tidak berhenti disaat ini saja. Peserta dapat mengimplementasikannya melalui metode pengajaran, seluruh siswa yang diajar, serta media pembelajaran yang dihasilkan.

\section{Ucapan Terima Kasih}

Kami dari tim pengadian mengucapkan terima kasih kepada seluruh pihak yang telah membantu terwujudnya pengabdian kepada masyarakat ini. Terutama kepada SD IT Luhuring Budi yang telah menyediakan tempat dan waktu pelatihan. Dan terima kasih juga diberikan kepada Fakultas Ilmu Komputer Universitas Lancang Kuning yang telah memberikan fasilitas pendanaan dalam pengabdian kepada masyarakat ini melalui kontrak pengabdian dengan nomor 400/fasikom/ pm/2021. 


\section{Daftar Pustaka}

Andriyani, S., \& Christy, T. (2018). Pelatihan Pembuatan Media Pembelajaran Berbasis Animasi Pada Smk Negeri 1 Air Joman - Kisaran. Jurdimas (Jurnal Pengabdian Kepada Masyarakat) Royal, 1(2), 15-18. https://doi.org/10.33330/jurdimas.v1i2.104

Arif, N., \& Arpin, R. M. (2021). Pelatihan Pembuatan Animasi Sebagai Media Pembelajaran Bagi Tenaga Pendidik di MIN 03 Luwu Pendahuluan Metode Pelaksanaan. 2(2), 202-206.

Hardiyanti, W. E., Ilham, M., Ekadayanti, W., \& Jafarudin, J. (2020). Pelatihan Pembuatan Video Animasi Gambar "Powtoon" bagi Guru PAUD. Abdimas Pedagogi: Jurnal IImiah Pengabdian Kepada Masyarakat, 3(2), 78-86.

Hasibuan, A. T., \& Prastowo, A. (2019). Konsep Pendidikan Abad 21: Kepemimpinan Dan Pengembangan Sumber Daya Manusia Sd/Mi. MAGISTRA: Media Pengembangan IImu Pendidikan Dasar Dan Keislaman, 10(1), 26-50. https://doi.org/10.31942/mgs.v10i1.2714

Jambak, M. I., Efendi, R., Yusliani, N., Al Qodrin, S., Haniffia, R., \& Dewangga, T. (2019). Pelatihan Pemanfaatan Aplikasi Digital dan Video Animasi Untuk Pembelajaran Bahasa Inggris di Panti Asuhan Siti Aisyah Palembang. Prosiding ANnual Research Seminar 2019, 5(2), 978-979.

Mardhika, M. M., \& Normawati, D. (2018). Pelatihan Pembuatan Media Pembelajaran Berbasis Tik (Animasi Flash) Di Smp Muhammadiyah Se-Kota Wonosari Kab. Gunungkidul. Jurnal Pemberdayaan: Publikasi Hasil Pengabdian Kepada Masyarakat, 1(2), 473. https://doi.org/10.12928/jp.v1i2.331

Nasution, N. (2018). Sosialisasi Aplikasi Manajemen Penelitian Dan Pengabdian Berbasis Online Di Lppm-Unilak. Dinamisia: Jurnal Pengabdian Kepada Masyarakat, 2(2), 107-112. https://doi.org/10.31849/dinamisia.v2i2.1256

Nasution, N., \& Hasan, M. A. (2019). Ibm Pelatihan Cms Content Dan Digital Jurnalistik. Dinamisia: Jurnal Pengabdian Kepada Masyarakat, 3(1), 22-30. https://doi.org/10.31849/dinamisia.v3i1.1482

Nasution, N., Hasan, M. A., \& Setiawan, D. (2018). Pelatihan Pembuatan Aplikasi Android Sebagai Bekal Technopreneurship Untuk Peningkatan Daya Ekonomi Mandiri Alumni Smk Di Pekanbaru. Jurnal Pengabdian Masyarakat Multidisiplin, 1(3), 219-234. https://doi.org/10.36341/jpm.v1i3.436

Nasution, N., Hasan, M. A., \& Setiawan, D. (2020). Sosialisasi Aplikasi Ujian Masuk bagi Calon Siswa Baru Universitas Lancang Kuning. Jurnal Laporan Abdimas Rumah IImiah, 1(1), 68-73. http://jlari.org/index.php/jlari/article/view/19

Nasution, N., Hasan, M. A., Studi, P., Informatika, T., Komputer, F. I., \& Kuning, U. L. (2021). IBM Aplikasi Keuangan Pada Sekolah Dasar Luhuring Budi Kecamatan Rumbai. 5(3), 754-762.

Sofwan, M., Jambi, U., Habibi, A., \& Jambi, U. (2016). Problematika Dunia Pendidikan Islam Abad 21 Dan Tantangan Pondok Pesantren Di Jambi. Problematika Dunia Pendidikan Islam Abad 21 Dan Tantangan Pondok Pesantren Di Jambi, 46(2), 271-280. https://doi.org/10.21831/jk.v46i2.9942

Wijaya, E. Y., Sudjimat, D. A., \& Nyoto, A. (2016). Transformasi pendidikan abad 21 sebagai tuntutan pengembangan sumber daya manusia di era global. Prosiding Seminar Nasional Pendidikan Matematika 2016, 1, 263-278. 